\title{
Correction to: Compromise and Action: Tactics for Doing Ethical Research in Disaster Zones
}

\author{
Jennifer Henderson and Max Liboiron
}

\section{Correction to:}

Chapter 15 in: J. Kendra et al. (eds.), Disaster Research and the Second Environmental Crisis, Environmental Hazards, https://doi.org/10.1007/978-3-030-04691-0_15

This book was inadvertently published without MOU (Memorandum of Understanding for Mutual Aid Research in Disasters Superstorm Research Lab \& Disaster Collaboratory). The current version of the book is published with MOU. 